Article

\title{
Exploring Livelihood Strategies of Shifting Cultivation Farmers in Assam through Games
}

\author{
Swen P. M. Bos ${ }^{1, *}$, Tina Cornioley ${ }^{1}$, Anne Dray ${ }^{1}$, Patrick O. Waeber ${ }^{1}{ }^{1}$ and \\ Claude A. Garcia 1,2 (D) \\ 1 ETH, Forest Management and Development Group (ForDev), Universitätstrasse 16, 8092 Zürich, \\ Switzerland; t.cornioley@gmail.com (T.C.); anne.dray@usys.ethz.ch (A.D.); \\ patrick.waeber@usys.ethz.ch (P.O.W.); claude.garcia@usys.ethz.ch (C.A.G.) \\ 2 CIRAD, UPR Forêts et Sociétés, F-34398 Montpellier, France \\ * Correspondence: swen.bos@usys.ethz.ch
}

Received: 5 February 2020; Accepted: 17 March 2020; Published: 20 March 2020

\begin{abstract}
Understanding landscape change starts with understanding what motivates farmers to transition away from one system, shifting cultivation, into another, like plantation crops. Here we explored the resource allocation strategies of the farmers of the Karbi tribe in Northeast India, who practice a traditional shifting cultivation system called jhum. Through a participatory modelling framework, we co-developed a role-playing game of the local farming system. In the game, farmers allocated labour and cash to meet household needs, while also investing in new opportunities like bamboo, rubber and tea, or the chance to improve their living standards. Farmers did embrace new options where investment costs, especially monetary investments, are low. Returns on these investments were not automatically re-invested in further long-term, more expensive and promising opportunities. Instead, most of the money is spend on improving household living standards, particularly the next generation's education. The landscape changed profoundly based on the farmers' strategies. Natural ecological succession was replaced by an improved fallow of marketable bamboo species. Plantations of tea and rubber became more prevalent as time progressed while old practices ensuring food security were not yet given up.
\end{abstract}

Keywords: Karbi Anglong (India); jhum; landscape change; socio-ecological system; role-playing game; companion modelling

\section{Introduction}

Shifting cultivation is still widespread throughout the tropics, constituting the main agricultural production system for the rural poor living predominantly in tropical forest margins. The practice consists of cutting, drying, and subsequently burning the aboveground vegetation to establish a temporary agricultural field. After crop production is done, the field is abandoned and a fallow period starts during which the natural vegetation is allowed to regrow. Landscapes shaped by shifting cultivation currently cover roughly 280 million hectares worldwide [1], with an estimated 30 and 40 million people directly depending on shifting cultivation in Southeast Asia alone [2,3]. There is no clear global trend that describes changes in the use of shifting cultivation. Farmers are still, maintaining, extending or departing from the practice [4-7].

However, there are differences between regions, and the drivers affecting the use and extent of shifting cultivation are not only strongly linked to changes in local demographics, such as population growth and migration, but also to economic development, road network development, market access, agricultural policies, and changes in public attitudes [4,8-10]. Both public policies and an increased 
access to economic structures (such as credits and cooperatives) can lead to a reduction in the area used for shifting cultivation [11,12].

Though shifting cultivation is often blamed as a main cause of both forest degradation and deforestation, it is the discontinuation of shifting cultivation, and its replacement by intensified land uses, that results in far larger negative environmental impacts [1], including the loss of biodiversity and reduced carbon stocks $[13,14]$. The patchy landscape, with vegetation of different ages regenerating and maintaining a high conservation value, both for flora and fauna, ends up becoming dominated by annual crops and/or permanent plantations grown in monocultures.

In Southeast Asia, the transition away from shifting cultivation is often also associated with higher household incomes and new livelihood strategies, but also in a significant decline in livelihood security. This was expressed by an overall reduction of customary practices, socio-economic wellbeing, available livelihood options and stable yields [15,16], coupled with a decrease of soil organic carbon content and aboveground carbon storage [17].

In this paper, we focus on the Karbi Anglong hills in central Assam, Northeast India. The hills are predominately used for a shifting cultivation system, locally known as jhum, and have not yet undergone significant changes (e.g., [18-20]), despite efforts by the Indian Government to replace the perceived ecologically harmful practices with more economic beneficial cash crop systems [20,21]. This case study allows us to analyse a shifting cultivation system together with the help of the jhum farmers, the actual landscape managers and change makers, before that change takes place. As shown, for example by [4], post-hoc analyses try to explain system changes in retrospect; here we have the opportunity to explore possible system trajectories based on the insights provided by the farmers themselves, given that the study area is not immune to socio-economic change. The national highway separating Kaziranga National Park and the Karbi Anglong hills is being developed to become India's main overland transport link to both China and Myanmar. Local roads into the hills are also developing. With rubber, bamboo and tea emerging as alternatives to jhum [21] for small-scale farmers, their decisions have the potential to shape both their livelihoods and the landscape.

To investigate jhum farmers' decision making and livelihood strategies, we adopted a constructivist approach based on participatory modelling [22-24]. We co-developed together with local jhum farmers a haptic model of their landscape in the form of a role-playing game and invited them to play out their livelihood strategies. Specifically, we examined (i) resource allocation: how jhum farmers allocated their resources (i.e., labour tokens and money) when having the opportunity to plant rubber and tea and sell bamboo, and (ii) sources of income: how their allocation strategies impacted their income in the game. From this, we identified their (iii) livelihood strategies: what their resource allocation revealed about their priorities and values concerning their livelihood, and recorded (iv) landscape cover change: what was the impact of the farmers' decisions on the game board mimicking their landscape.

\section{Methods and Materials}

The case study was conducted in Assam (North Eastern Region of India), in the district of Karbi Anglong. The region is home to over 220 different ethnic groups, many of them still practicing their traditional shifting cultivation [20,25]. The northern Karbi Anglong hills (Figure 1) overlook the Brahmaputra flood plains and border Kaziranga National Park, a UNESCO world heritage site, renowned for its biodiversity and flagship species, such as the Asian rhino, elephant and tiger [26]. The hills also provide a critical refuge for wildlife during the annual monsoon flooding of the park. This study site was selected for its ecological dependency on Kaziranga on the Karbi forests, and the local constitutional arrangement. The Assam state government has limited control over the autonomous district and its land use policies [27]; these allow the Karbi farmers to remain the principle landscape managers, free to practise their traditional Jhum system, or explore alternatives.

Local jhum farmers clear the forest to grow rain-fed upland rice, vegetables and cash crops such as ginger, chillies and sesame. Clearing a field establishes ownership, according to local traditional customs. After one or two growing seasons, the field is abandoned, and weeds and bamboos are 
allowed to initiate ecological succession, until secondary forest is re-established [28] (and references therein). Villages are located in the valleys, which also allow some farmers to grow paddy rice.

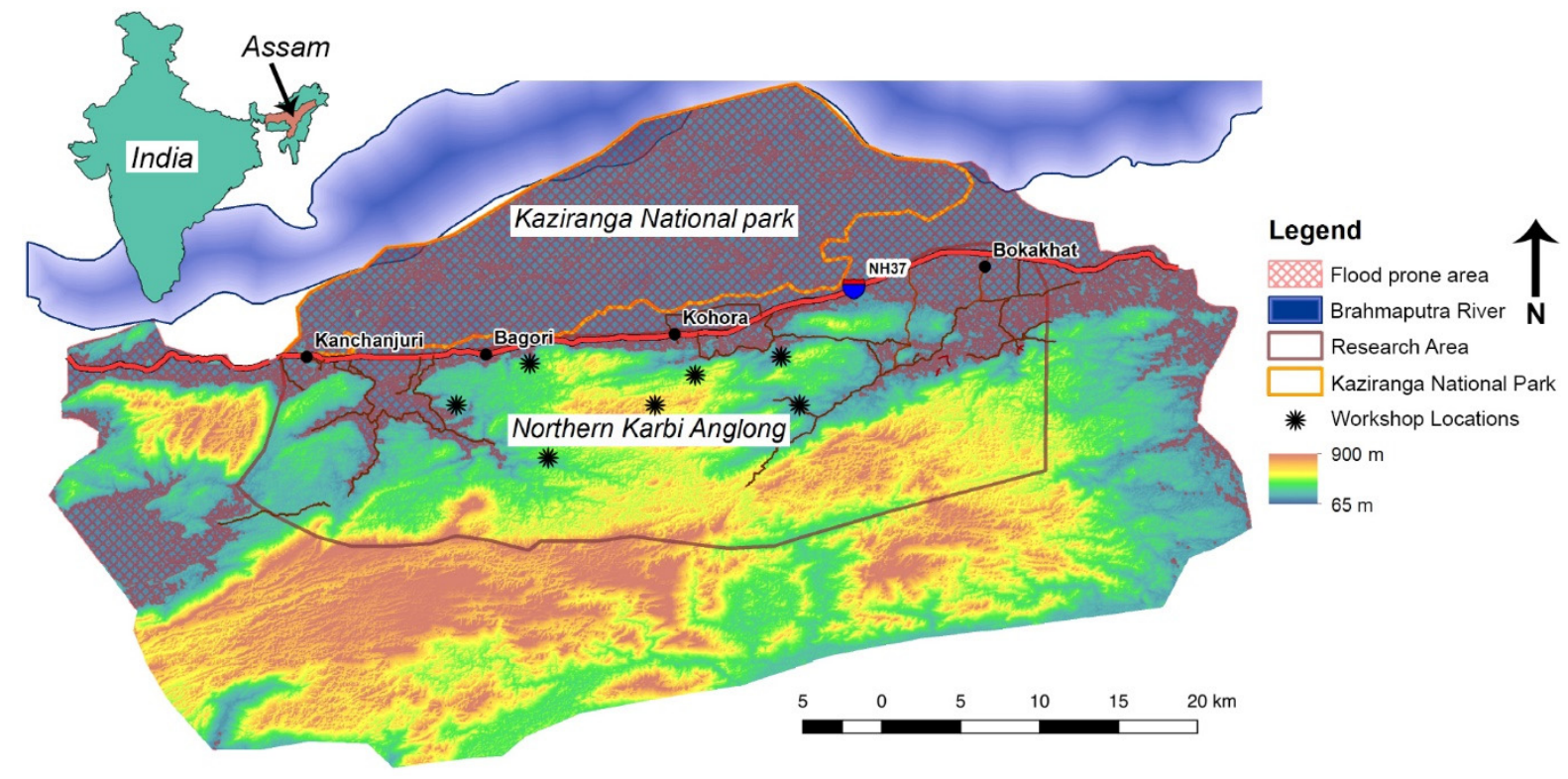

Figure 1. The northern hills of the Karbi Anglong district, located in central Assam, India (adapted from [29]).

\subsection{Participatory Approach}

We use the companion modelling approach [30-32] to co-construct with local farmers a shared representation, a model, of their farming system and landscape in the form of a role-playing game. The foundation of companion modelling is the willingness to incorporate on equal footing the multiple and often conflicting viewpoints of the stakeholders into a single model, validated by all stakeholders involved in the process [33-35]. Through workshops facilitated by the research team, stakeholders collectively decide and organise the knowledge they consider relevant for the problem at stake (e.g., [36,37]).

The role-playing game is a tool for eliciting human decision making and strategy development [32]. In such a game, the outcomes of one action depend on the interactions between one's decision, the decisions of the other players and the rules of the game [32,33]. Each game session represents a simulation of a "model of a strategic situation". A strategy here is a series of decisions made by the same agent and fed with feedback on the state of the world. It can be either a good or a bad one depending on how the player perceives the outcome matching his or her expectations. Feedback in this context can be either accurate, wrong or inexistent. We exclude objectives from the definition of a strategy as changing objectives mid-course itself can be a strategic decision.

Developing and using models able to trigger real behaviour in participants is essential for both increasing our understanding of how the system at hand, e.g., the Karbi Jhum system, works. It also allows for validating the outputs of the simulation. There are several ways to assess whether the behaviour participants expose during game sessions is realistic. A debriefing session after a game is an essential step to discuss and share the dynamics experienced during the game. Additional individual interviews after the game session facilitate more in-depth discussions bridging the game dynamics and deployed strategies with real life.

This study is not the first to use a role-playing game to explore landscape management and household investment strategies of shifting cultivation farmers, and their impacts. Player strategies of paddy and upland rice farmers in Vietnam were, for instance, used to successfully build an agent-based model of landscape change at regional level, and supported learning, trust building and collective action at local level with multiple stakeholders [38]. 


\subsection{Model and Game Development}

In Figure 2 we present four main components of the methodology used for this study. First, we created a general understanding of the system, for which we used group interviews, individual interviews and satellite data analysis. We built the conceptual model that forms the basis of the Jhum system through an iterative process with a focus group of 10 farmers in 2 different villages, identifying the most important resources and actors, their interactions and dynamics [31]. This phase also allowed us to identify the main issues facing the different stakeholders. In the second phase, we co-developed a scenario and the role-playing game that allowed us to explore jhum farmers' preferences with regard to four agricultural development opportunities that are currently emerging in the local Jhum system: (a) increase the production of cash crops, (b) plant bamboo in the fallows, (c) establish a tea plantation or (d) plant rubber. The conceptual model was turned into a role-playing game. In this process, actors become players, resources become game tokens, and ecologic and economic dynamics become rules or game phases (for a full description of the game, see Video S1, Supplementary Material 1). This requires proportional calibration, to ensure the implicit reality of the game is still meaningful for the players and remains reflective of the local system, as well as to accelerate the game and make it playable by non-experts. Together with the stakeholders, we quantified yields, prices, labour demands throughout the growing season, household expenditures, fallow dynamics and bamboo growth, soil fertility regeneration and market dynamics, using group interviews, ranking exercises and individual interviews. This process also allowed for the system understanding to continuously be improved. A total of 36 individual interviews were conducted, and 16 game model development workshops were organised in the same three villages to build, parameterise, calibrate, gamify, test and verify the model, with over 60 local stakeholders in total participating in the process. An additional four villages were selected for playing the simulation with local jhum farmers (Figure 1).

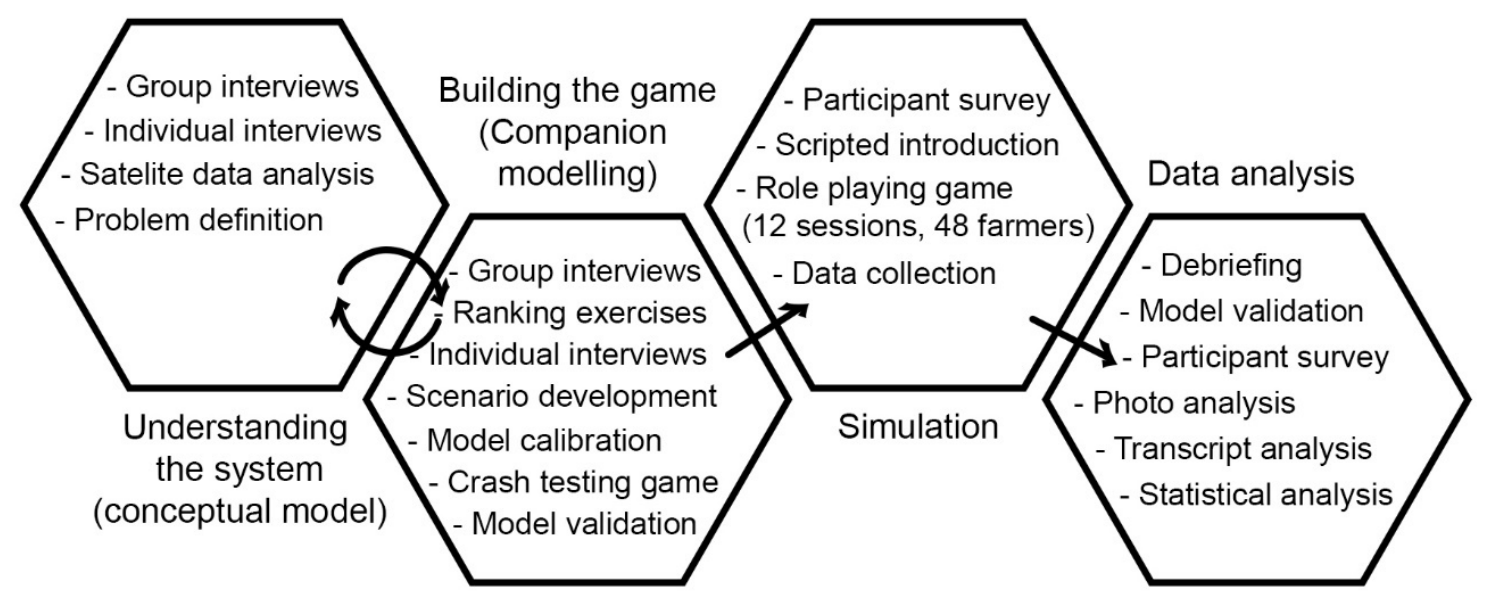

Figure 2. Schematic overview of the study structure. The first two components are interlinked, while the game and scenario are developed, and calibration takes place, the system understanding continues to be improved. Once the game was constructed, we organised sessions to run the simulation with the local jhum farmers. After the simulation data analysis started, initially together with the participants in the debriefing session and an individual survey, while the analysis of the recorded data was done separately.

\subsection{Role-Playing Game Description}

The game explores how jhum farmers secure their livelihood and shape the landscape. Players embody the role of jhum farmers and can invest and allocate labour tokens and game money into different activities to produce crops for sale or home consumption, or to improve their standard of living (Figure 3a). Their actions, in turn, affect the composition of the landscape. The game has three distinct components; the board that represents the Landscape, the players' Households that represent 
the standard of living of the farmers, and the Market that represent all the transactions with the outside world (Figure 3a).

a

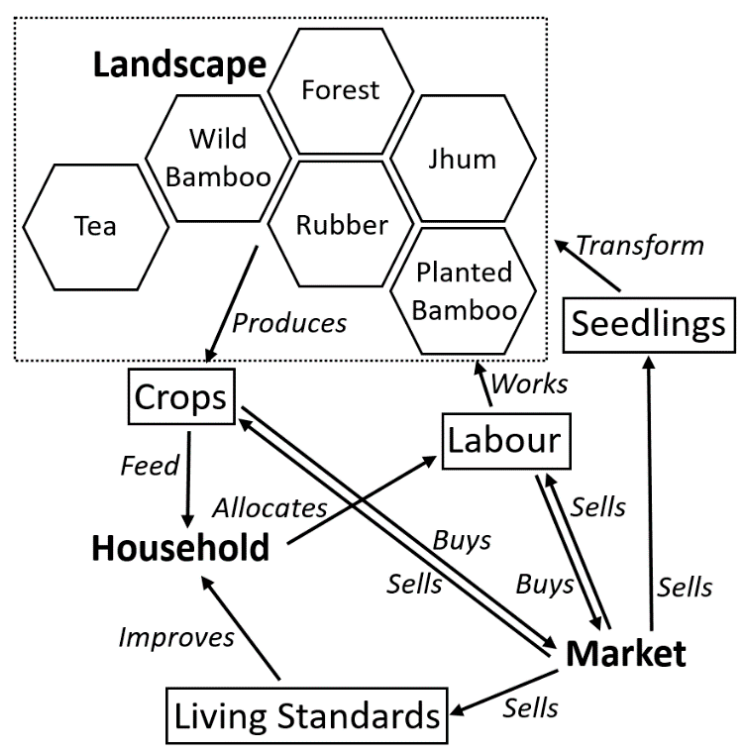

b

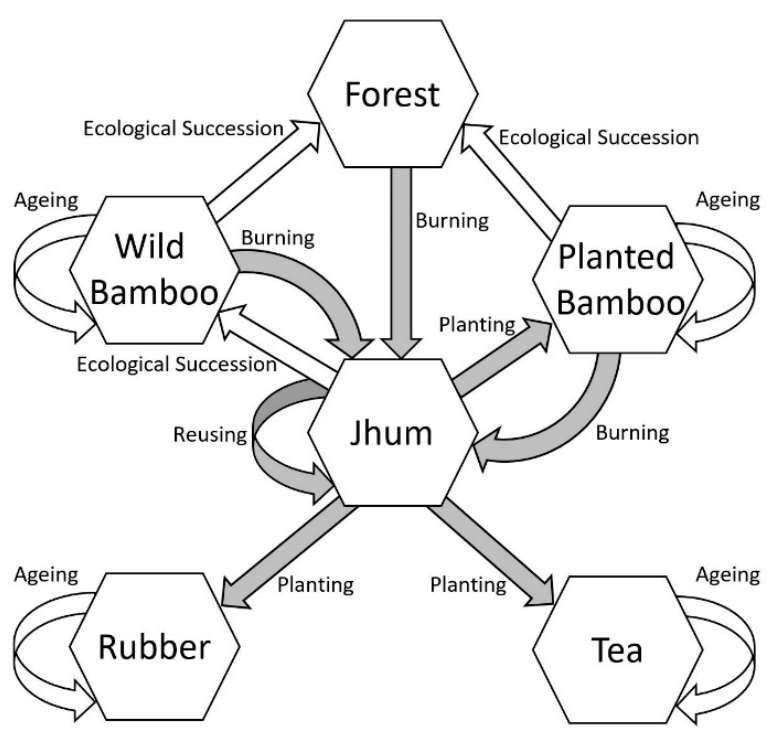

Figure 3. (a) The model used in the game. The three main game components are shown bold. The landscape is where production takes place, labour is invested and seedlings for establishing rubber and tea plantations are planted. The player's household supplies family labour, requires food for home consumption and can be improved by buying living standard tokens from the market. The market can be used to provide additional labour and food, as well as allowing for investments in rubber and tea seedlings and improvements to the players' living standards. Game money is not shown as a separate resource, as it is used to facilitate all the other transactions in the model. (b) The model's landscape dynamics are the result of ecological succession and player management. The white pathways are natural processes transforming a landscape tile from one state into the next, while the grey pathways indicate transformations that are the result of interventions made by the players.

The Landscape (game board) is where the players choose to clear forest and plant their crops, allocate their labour and plant bamboo, tea or rubber plantations, or allow forest to naturally regenerate. The initial landscape composition is based on the analysis of Landsat 5, 7 and 8 satellite images of the research area, spanning the period between 1988 and 2015. This was done to ensure that the landscape at the start of the simulation is representative of the general situation on the ground, though not an exact copy of any specific location or village, thus representing an implicit reality. The game board is made of tiles. Each tile has a specific land cover type (either forest, jhum, wild bamboo, planted bamboo, rubber or tea), and the transitions between different land cover types are based on the decisions of the players and on a set of rules mimicking the ecological succession of the fallows and forests [39] (Figure 3b).

The game is played in rounds, each round representing the passing of time, loosely covering one growing season. Between rounds, the landscape becomes two years older, with the second round representing the state of the system three years after the start of the first round. This is done to allow for incorporating long-term processes, without the need for playing too many rounds. The age of a tile since the last burn event is a proxy for its seral stage and allows for vegetation growth and soil fertility regeneration to be represented in the model. The soil fertility of the tile determines the yield of a crop. Colour codes on the landscape tiles indicated the degree of fertility if converted into a Jhum field.

Players allocate labour to their fields. Labour allocation was measured in labour tokens, each representing six weeks of work for an adult jhum farmer. Players could allocate labour to harvest 
bamboo, maintain and harvest rubber and tea plantations (the two plantation crops), and to grow rice, vegetables or cash crops (the three jhum crops).

The Household is where players can choose to improve their standard of living, store their harvest and save their money. When improving the standard of living, the players can choose to buy tokens and allocate these to reflect investments on five different parameters: healthcare, housing, education, religious activities and 'family', which covers life improvements such as weddings, buying meat for dinner more often, new clothes, travelling, etc. The standard of living tokens have a fixed price, independently of where they are allocated.

The market in the game is where extra labour can be hired or excess labour can be sold, rice and vegetables can be sold or bought to meet family food needs, bamboo and cash crops can be sold by the farmers and materials for establishing plantations of tea and rubber can be bought. The market is managed by the research team. We used game money, Karbi Tanka (KT), as game currency. Yields and crop value were derived from interviews and model development workshops. Tea and rubber plantations require additional labour and monetary investments for two rounds before they reach maturity and generate a profit. All the other activities yield returns in the same round. Supplementary Material 2 (Tables S1-S3) provide details on the in-game, labour demands, yields and prices.

\subsection{Session Organisation}

The game was played with a total of 48 jhum farmers during 12 separate workshops, spread over 7 different villages in the Northern Karbi Anglong, from September to December 2016 (Figure 1). The Participants were selected semi-randomly in each village the day before the workshop, inviting those willing and able to join in the simulation. We invited only active jhum farmers, both male and female, young and old. The participants were compensated twice the locally going daily wages. This would allow players to hire someone to do the farm work that would need to be done during the busy harvest season, while also compensating the players for their own time. The payment was independent of the player's performance in the game.

Each session had the same starting conditions, with the initial landscape (game board) reflecting a mosaic of secondary forest and fallows. The workshops were held in the local language, Karbi, and the introduction to the workshop and the game were done following a written script (Supplementary Material 3), to ensure all games were introduced through the same procedure. The players were given the objective to acquire enough rice to feed their family. No other game objectives were given, allowing the players to develop their own strategies, and define their own objectives as the game unfolded.

The game is played for six rounds, with each round consisting of nine consequential steps (Table 1). One game session represents 18 years of landscape change. The first round was used to familiarise the players with the game and its rules. Most players did not have problems playing after round one.

The session ends with a debriefing, which allows players to reflect on their experience during the game, compare strategies, and discuss links with the real system. Players develop narratives to explain the decisions they took in the game, and we discussed differences and similarities between what happened in the game and what happens in real life. The debriefing is thus also used to validate the model and its outputs [40]. 
Table 1. Game round structure. The tasks of the players and research team during each step of a game round.

\begin{tabular}{|c|c|c|}
\hline Step & Player & Research Team \\
\hline 1 & $\begin{array}{c}\text { Select jhum land, convert tiles to jhum, claim land } \\
\text { ownership. }\end{array}$ & Note tile types chosen for conversion to jhum. \\
\hline 2 & Hiring and allocating labour. & Note labour purchases and allocation. \\
\hline 3 & Planting jhum crops. & $\begin{array}{l}\text { Note \# of each crop type planted, take } \\
\text { photograph of landscape. }\end{array}$ \\
\hline 4 & Harvesting crops and bamboo & \\
\hline 5 & $\begin{array}{l}\text { Selling harvests at the market and buying rice (if needed), } \\
\text { standard of living tokens and plantations. }\end{array}$ & $\begin{array}{l}\text { Note \# tokens sold/bought/kept and plantation } \\
\text { seedlings bought. } \\
\text { Update landscape age and resources, except jhum } \\
\text { fields, for next round. }\end{array}$ \\
\hline 6 & Allocate standard of living tokens. & $\begin{array}{l}\text { Note token allocation, take photograph of } \\
\text { household sheet. }\end{array}$ \\
\hline 7 & Pay plantation management costs. & $\begin{array}{l}\text { Track player seedling/plantation ownership and } \\
\text { payments. }\end{array}$ \\
\hline 8 & Meet family food requirements. & Collect rice and vegetable tokens. \\
\hline \multirow[t]{2}{*}{9} & $\begin{array}{l}\text { Replace old jhum with planted/wild bamboo or } \\
\text { plantations. }\end{array}$ & $\begin{array}{l}\text { Count money left in each player's household, } \\
\text { update landscape. Take photograph of landscape. }\end{array}$ \\
\hline & Next round. & \\
\hline
\end{tabular}

\subsection{Data Collection}

The data were gathered via note taking, photographs and audio recordings (cf. Table 1). Prior agreed consent was asked for and data were used anonymously and confidentially based on the KFPE (Swiss Commission for Research Partnerships with Developing Countries) principles [41]. During the game sessions and for each round, we recorded players' decisions and the associated reward, which included (a) players' labour allocation to different crops, (b) player's money allocation to different categories of living standards, and (c) players' income from different sources. Players could allocate money to hire labour, buy rice and vegetable tokens, buy and plant two plantation crops (tea, rubber), and invest into the five standard of living parameters (education, health, house, religion, and family). We assumed that the money allocation to the different investment opportunities, as well as the standard of living categories, is reflective of the player's strategic priorities. Their income could come from the three jhum crops, planted bamboo, the two plantation crops rubber and tea, and from selling family labour. We further recorded the number of landscape tiles of each landscape cover type among forest, jhum, planted bamboo, wild bamboo and the two plantations crops for each round.

\subsection{Data Analysis}

All decisions made by the players, such as labour token placement, the number of plantations bought, standard of living investments made, crops produced and bamboo harvested, were recorded during the workshops by members of the research team. Photographs were taken of the landscape and the player household sheets to allow for double-checking the data recorded (Table 1). Part of the data analysis already happens together with the participants, discussing the strategies deployed during the game together, and their implications, in the debriefing, as well as in the participant survey after the workshop (Figure 2). The debriefing sessions were recorded on voice recorders and video for subsequent transcriptions and translations. These discussions allowed us to better understand the reasoning behind observed decisions made by the players during the simulation. As the debriefing sessions with the players themselves were discussions of the results observed during the workshops, we added their discussion inputs into our discussion section.

In a first step, we examined players' decisions and their associated rewards over each round. We then investigated the cumulative monetary return for the cumulative labour investment and for the 
cumulative monetary investment at the end of the game. Finally, we analysed landscape cover changes over rounds. All data analyses were performed in R [42].

Labour allocation: We investigated trends in number of labour tokens dedicated to the different crop types over round by fitting a generalised additive mixed effect model (GAMM) with a Poisson distribution from the package MGCV (version 1.8-6, [43]) to account for nonlinearity. We used a full tensor product smooths for the fixed continuous effect round. The same procedure was applied for the other GAMMs performed in this study, except when stated otherwise. We fitted one model for each crop type plus one for the cover type jhum, regrouping the three jhum crop types (rice, vegetables and cash crops). In all models, we accounted for the random effects of the player ID and the village ID.

Money allocation: Similarly to labour allocation, we fitted a GAMM to examine the trend over round of the monetary expenditures (non-cumulative) of the players for each money allocation category except for the standard of living improvement which were grouped together into one category. In a second step, we analysed the cumulative monetary expenditure of the different standard of living separately over round with a generalised linear mixed effect model (GLME) from the LME4 package (version 1.1-17, [44]) with a Gaussian distribution, again treating player ID and village ID as random effects. The response variable, cumulative monetary expenditure, was square root transformed to fulfil criterion of the Gaussian distribution.

Player income: To evaluate the monetary gain of labour allocation strategies and of money allocation strategies, we investigated the relationships between the cumulative income at the end of the game per cumulative number of labour tokens allocated to each category and per cumulative amount of money allocated to each category. In both cases, we fitted a GLME with a Poisson distribution and a square root link function and included player ID and village ID as random effect. The first model included the two fixed effects, round and crop type. Crop type included jhum (regrouping the three jhum crop types), rubber, and tea. Even though players could also allocate labour to bamboo, this category was excluded from the model because one labour token allocated to bamboo always generates $270 \mathrm{KT}$ each round, as determined by the game mechanism. There is, thus, no variability in this relationship. The second model included round and investment category. The investment categories included jhum (regrouping the three jhum crop types), rubber, tea and hired labour. The income generated by labour hired from the market was calculated using the average income generated by one labour token for each player for each round. Bamboo and standard of living improvements were excluded from the model. The former, because it requires no monetary investment, and the second, because it does not generate revenue. It should be noted that the cumulative income generated by labour allocation to jhum varies depending on the combination of jhum crops planted. The cumulative income generated by labour and money allocated to rubber and tea likewise varies as it depends on the age of plantation at the end of the game. A young plantation will not have had time to generate income, in contrast to a 6-round old plantation.

Landscape cover changes: For each cover type, we fitted a GAMM with round as a fixed effect, and workshop ID as a random effect. The changes in the landscape cover round as the result of a 'no human intervention' scenario were included as a baseline.

\section{Results}

\subsection{Labour Allocation}

Over the course of the game, players allocated most of their labour tokens to jhum (mean $=5.66$ tokens per round, $\mathrm{SD}=1.12$ tokens per round) which also remained their main source of income throughout the game (mean $=562.74 \mathrm{KT}$ per round, $\mathrm{SD}=218.11 \mathrm{KT}$ per round), closely followed by harvesting planted bamboo (mean $=515.16 \mathrm{KT}$ per round, $\mathrm{SD}=386.24 \mathrm{KT}$ per round). Most of their wealth was invested into improving living standards (mean $=760.41 \mathrm{KT}$ per round, $\mathrm{SD}=368.76 \mathrm{KT}$ per round), in particular education, with important variation amongst the players (mean $=232.29 \mathrm{KT}$ per round, $\mathrm{SD}=160.68 \mathrm{KT}$ per round). In each session, few players planted tea and/or rubber 
$($ mean $=3.25$ players owned a tea plantation per session, $\mathrm{SD}=1.05$, mean $=1.08$ players owned a rubber plantation per session, $\mathrm{SD}=0.90$ ), and plantations never represented more than $16.27 \%$ of the landscape (mean $=9.1 \%$, $\mathrm{SD}=4.40 \%$ ).

Labour allocated to jhum followed a slow downward trend over the rounds, while labour allocated to harvesting bamboo, cultivating tea and rubber increased over the rounds (Figure 4a). Models for the number of labour tokens allocated to different land cover described $9.6 \%, 46.8 \%, 87.4 \%$ and $70.9 \%$ of the deviance for jhum, planted bamboo, rubber and tea, respectively. In all cases, the smoothing term for round differed from zero $(p<0.001)$. The labour requirements of rubber plantations are three times as high as those of tea, however, more labour was allocated to tea. The total number of labourers hired increased over rounds from 0 in round $1(\mathrm{SD}=0)$ to $2.208(\mathrm{SD}=2.018)$ in round 6.

The players invested most of their labour in jhum (as shown in Figure 4a), with rice being given a higher priority than cash crops and vegetables (Figure $4 \mathrm{~b}$ ). However, the distribution of these crops varied amongst the players. Though growing cash crops on jhum land is the most profitable activity in the game, there is no indication that the farmers increased their production. The model estimated an overall decrease over time without obvious differences in slopes between the crop types. Selling family labour was not a strategy employed by the players in the game.

a)

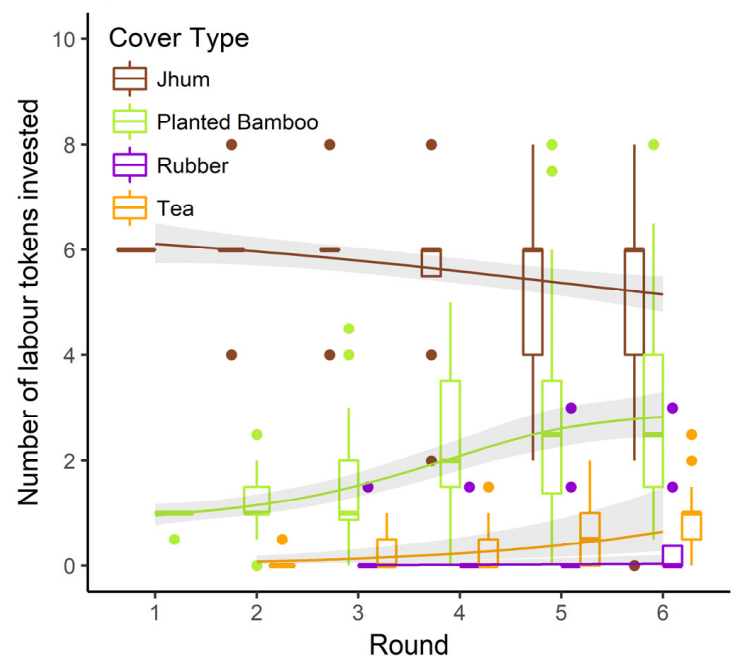

b)

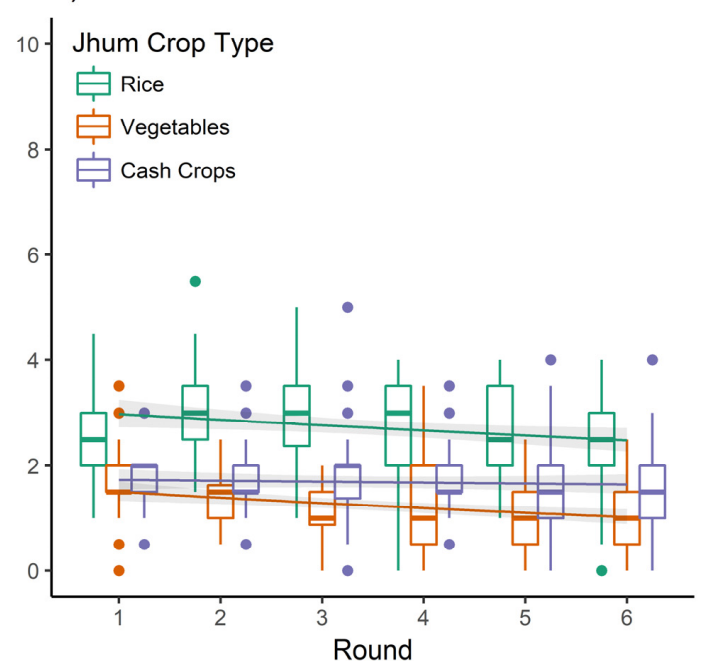

Figure 4. Labour allocated to the different land cover types (a) and crop types (b), per round. The boxplots and the dots represent the dispersion of the observed data. The lines are the predictions from generalised additive models accounting for the nested random effects of the players with village ID. The grey area represents the $95 \%$ confidence intervals. ((a) In all cases, the variation in the number of labour tokens allocated increased over rounds (GLME model: intercept (reference Jhum) $=-0.052$, $\mathrm{SE}=0.113$, additional effect for tea $=-0.053, \mathrm{SE}=0.151$, additional effect for rubber $=-0.145, \mathrm{SE}=0.151$, round effect $=0.199$, additional effect for bamboo $=-0.078, \mathrm{SE}=0.151$, round effect $=0.199, \mathrm{SE}=0.027$, additional round effect for tea $=-0.107, \mathrm{SE}=0.039$, additional round effect for rubber $=-0.056, \mathrm{SE}$ $=0.039$, additional round effect for bamboo $=0.070, \mathrm{SE}=0.039$, with workshop as a random effect); (b) GLMER model: intercept (reference rice) $=1.822, \mathrm{SE}=0.056$, additional effect for vegetables = $-0.644, \mathrm{SE}=0.099$, additional effect for cash crops $=-0.570, \mathrm{SE}=0.092$, round effect $=-0.036, \mathrm{SE}=0.015$, additional round effect for vegetables $=-0.040, \mathrm{SE}=0.024$, additional round effect for cash crops $=0.026$, $\mathrm{SE}=0.024)$.

\subsection{Money Allocation}

Every round, players consistently allocated most of their money to improving their standards of living (Figure 5a). Spending on the other categories was considerably less. The players moderately increased their spending on hired labour, buying rice and planting tea as the rounds progressed (Figure 5a). The models for the money allocated to different categories described 37.1\%, 57.2\%, 44.7\%, 
$31.3 \%$ and $57.2 \%$ of the deviance for living standards, hired labour, rice bought, tea, rubber, respectively. In all cases, the smoothing term for round differed from zero $(p<0.001)$. Most players, 39 out of the 48 participants, invested money in tea before the end of the game, while 17 of the players chose to invest in rubber. However, the total investment, compared to the other spending categories was small.

The workshop participants allocated money to one of five categories amongst education, health, house, religion and family to improve their standard of living. The cumulative investments in education were higher than in any of the other categories, and remained so as the game progressed (Figure 5b).

a)

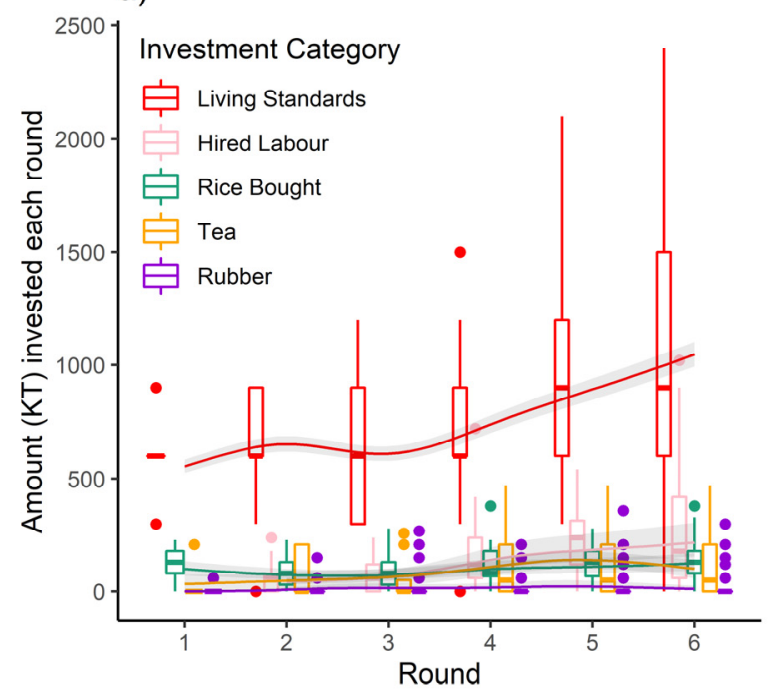

b)

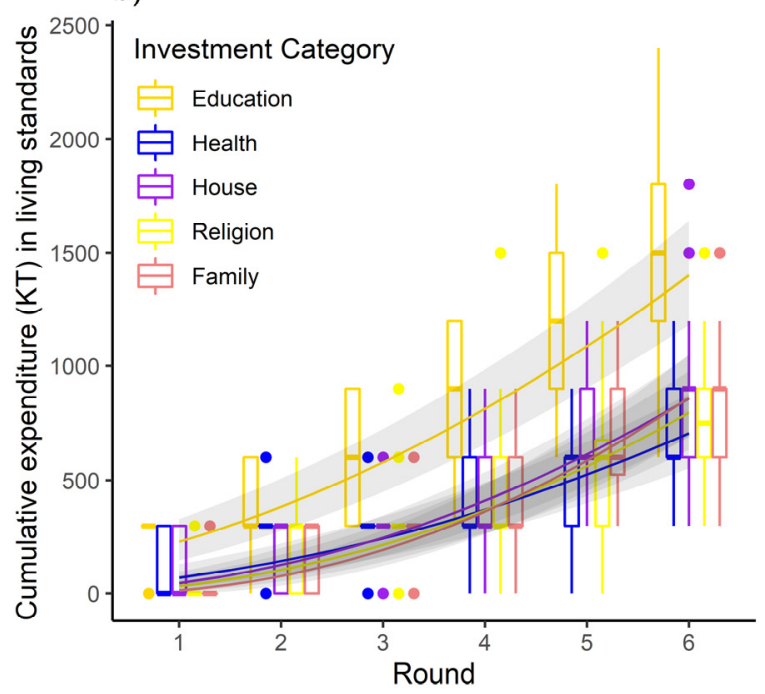

Figure 5. Monetary investments. Investment in the different categories per round (a) and cumulatively for the different standard of living categories $(\mathbf{b})$. The boxplots and the dots represent the dispersion of the observed data. The trends are the predictions from the models, the grey area, the corresponding $95 \%$ confidence interval, including the variation from the random effects. Jhum and bamboo are not shown since they require no monetary investment. The model describing cumulative investment over round per standard of living investment category estimated a higher initial investment into education than into the other categories, with the lowest initial investment allocated to family ((b) GLME model performed on the squared root of the response variable: intercept (reference education) $=10.688, \mathrm{SE}=$ 0.935, additional effect for health $=-5.986, \mathrm{SE}=1.219$, additional effect for house $=-8.455, \mathrm{SE}=1.219$, additional effect for religion $=-9.483, \mathrm{SE}=1.219$, additional effect for family $=-12.194, \mathrm{SE}=1.219$ ). There were no differences in the rate at which cumulative investment increased over round between education, house and religion, whereas cumulative investment in health increased at a slower pace and family at a faster pace compared to education (round effect $=4.459, \mathrm{SE}=0.221$, additional round effect for health $=-0.817, \mathrm{SE}=0.313$, additional round effect for house $=0.051, \mathrm{SE}=0.313$, additional round effect for religion $=0.042, \mathrm{SE}=0.313$, additional round effect for family $=0.685, \mathrm{SE}=0.313$ ).

\subsection{Players' Income}

Players could receive an income for their investment in labour and/or money into different activities, as determined by the game mechanisms. Jhum was the main source of income for most players and harvesting bamboo, second (Figure 6). Yet one labour token allocated to bamboo generated a cumulative higher income compared to a labour token allocated to jhum (Figure 6a). As jhum and bamboo only requires labour allocation and no financial investments, these activities generated income for a cumulative financial investment of zero (Figure $6 b$ ).

Many players failed to generate income from allocating labour and money to tea and rubber (18 out of 39 and 11 out of 17 respectively, Figure 6). Players investing into plantations chose to invest mostly in tea rather than in rubber ( 39 vs. 17 players respectively), yet the players who invested in rubber derived, on average, higher income from each labour token and each monetary unit allocated 
to this plantation type compared to those investing in tea. Even though allocating money to improving standard of living is not an income generating activity in the game, this is the category to which players allocated the most money (Figure 6b).

a)

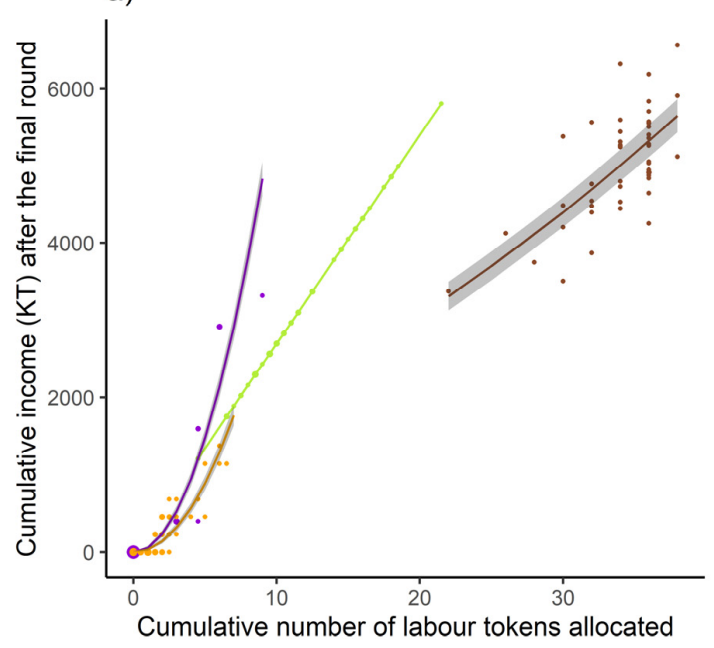

b)

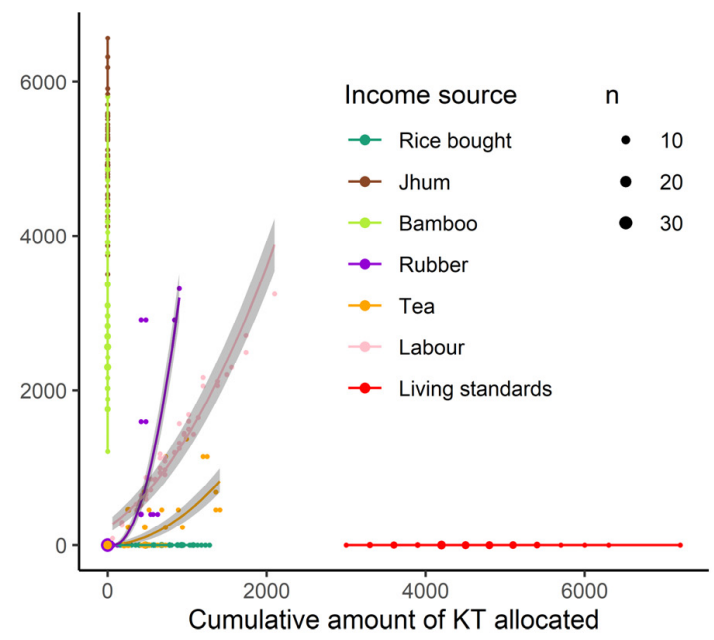

Figure 6. Total cumulative income generated at the end of the game. (a) Through the cumulative number of allocated labour tokens (cf. Table 2), and (b) through financial investment in the different categories (cf. Table 3) over the course of the game. The dots represent the observed data, the size of the dot reflects the number of observation at each location. The trends are the predictions from the models, the grey area, the corresponding $95 \%$ confidence interval, including the variation from the random effects.

Table 2. Model description for Figure 6a, Labour token allocation: GLMER model on the square root of the response variable.

\begin{tabular}{ccc}
\hline Effect At The Intercept Of: & Value & SE \\
\hline Jhum & 46.930 & 0.989 \\
Rubber & 95.465 & 0.881 \\
Tea & 94.158 & 0.953 \\
Cumulative Labour & 17.115 & 0.940 \\
\hline
\end{tabular}

Table 3. Model description for Figure 6b, Financial investment: GLMER model on the squared root of the response variable.

\begin{tabular}{ccc}
\hline Effect At The Intercept Of: & Value & SE \\
\hline Rubber & 39.656 & 3.066 \\
Tea & 13.75 & 1.640 \\
Labour & 29.782 & 1.548 \\
Cumulative KT For Rubber & 28.266 & 3.617 \\
Cumulative KT For Tea & 8.269 & 1.693 \\
Cumulative KT For Labour & 9.282 & 1.183 \\
\hline
\end{tabular}

\subsection{Landscape Cover}

The Landscape (gameboard) evolved from a wild bamboo and forest dominated landscape to a planted bamboo dominated landscape (Figure 7a). The same initial landscape left unexploited would have evolved towards a forest dominated landscape (Figure $7 \mathrm{~b}$ ). The decrease of wild bamboo happened in both settings reflecting ecological succession, as after six rounds, wild bamboo turns into secondary forest. The same applies to planted bamboo; left unmanaged, planted bamboo turns 
into forest after six rounds. The area dedicated to jhum decreases gradually over game round while plantations of both rubber and tea are slowly appearing into the landscape (Figure 7a). The models for forest, jhum, planted bamboo, wild bamboo and plantation cover over round described $78.7 \%$, $29 \%, 97.1 \%, 95.1 \%$ and $85.0 \%$ of the deviance, respectively. In all cases, round was found to have a smoothing term different from zero $(p<0.001)$.

a)

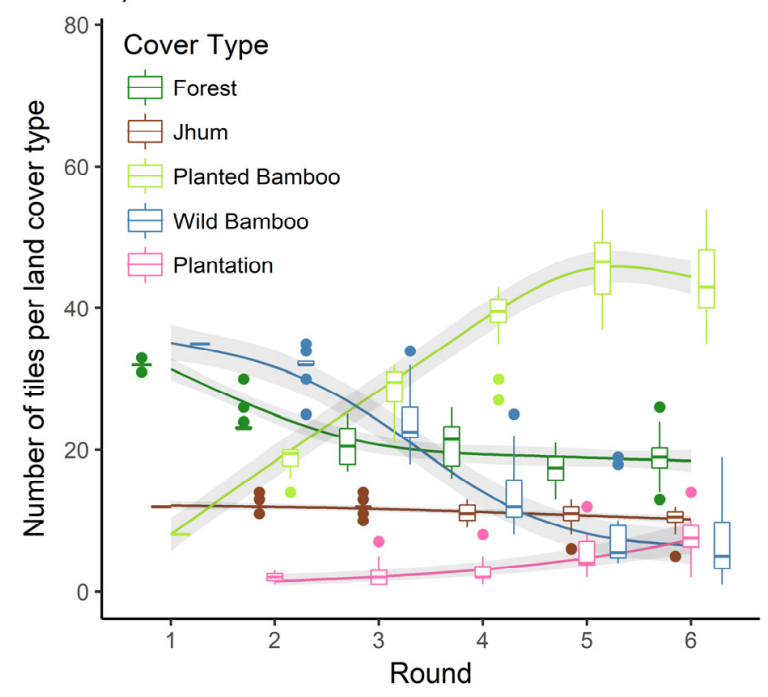

b)

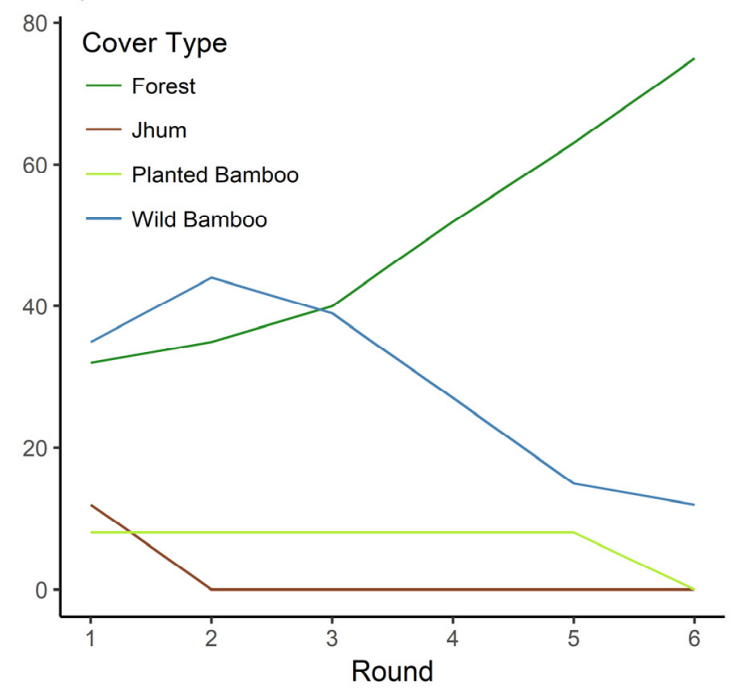

Figure 7. Trajectory of landscape composition as exploited in the game (a) versus baseline landscape with natural succession only from round 2 onwards (b). The boxplots and the dots represent the dispersion of the observed data, and the lines are the predictions from generalised additive models accounting for the nested random effects of the players with villages; the grey area represents the $95 \%$ confidence interval and the variation from the random effects (a).

\section{Discussion}

In this study, we examined the strategies of small-scale farmers from the Karbi Anglong hills in India immersed in a role-playing game representing their socio-ecosystem. In addition to planting jhum, farmers had the possibility to harvest and sell bamboo and plants and sell rubber and tea, representing economic alternatives that have recently become available in the area $[21,45,46]$.

The maintenance of jhum cultivation alongside the increase in bamboo harvesting suggests that farmers are not aiming at maximising their income per unit of labour. One of the reasons brought forward by the players during the game sessions was that jhum rice is considered to be tastier than food from the market, and they attributed higher health benefits to rice and vegetables intercropped and grown on their jhum. Wangpan and Tangjang [47] pointed out similar findings for the Arunachal Pradesh region of India, where jhumming plays an important role harbouring precious germplasms of different indigenous plant species, which are also selected for taste preferences and nutritional benefits. Dietary diversity has been found to be higher under a jhum regime in comparison to other cash cropping systems [48]. Mixed- or multi-cropping systems are more resilient to disturbances [49]; however, mixing more species requires more work and knowledge, especially about timing. Jhum is hard work (e.g., seeding, weeding, planting, guarding crops from wildlife, harvesting). Reducing workload was often cited by participants of the game as one of the main reasons to develop alternative income strategies, echoing the position expressed by other farmers from similar systems [16]. However, the reluctance of abandoning shifting agriculture, even when other options are available, is not unique to this case study [50,51].

Fewer resources were invested into rubber and tea compared to any other investment alternative in the game despite both being perceived by the participants as a good investment. However, tea was planted much more than rubber. The lowlands in Assam have been used for growing tea since colonial 
times [52]. Based on game workshop participants' statements, owning a tea garden is a status symbol, and perceived to be a path to wealth. Within the research area, one can already observe a few small tea gardens being established by local farmers, reflecting the strategies deployed in the game. This indicates a lower barrier of entry. Planting tea is also recognised as a low risk investment, mainly because crop-raiding wildlife such as elephants tend to avoid tea gardens; tea seems not to be palatable to elephants [53]. However, depending on tea for household income has its drawbacks, as harvested tea needs to be cured the same day, and this can locally only be done at the large tea estates. These estates are in full control of the prices offered to outside producers, and the better prices are associated with high quality requirements that are hard for small-scale farmers to meet [54]. The tea estates also have irregular demand for freshly plucked tea and can only accommodate tea from outside producers when their own fresh tea production does not meet production capacity [54]. It may be because of these constraints— known to famers but not incorporated in the game mechanism - that establishing tea plantations was not one of the prevailing strategies in the game.

India is one of the world's leading rubber producers with over $88 \%$ of its production being placed in the smallholder sector [55]. Rubber represents potentially an interesting crop for smallholders due to its qualities of intercropping. It can be intercropped for both short rotation and long-term agroforestry systems [56]. In the game, more labour and money was invested in establishing tea plantations than for planting rubber, even though the long-term rewards of rubber are much larger and the work was also perceived as easy and light, comparatively. The participants in the game workshops, however, have no real-life experience in growing and harvesting rubber themselves. Human-wildlife conflicts are prevailing in Assam, especially elephants as the main crop-raiders [57]. The vicinity of Kaziranga National Park is perceived by the players as extra risk to investing in rubber plantations with fencing investments being prohibitive for the small-scale farmers. According to the participants in the game workshops, only a few young rubber plantations have been established by non-jhum farmers in the area so far, and the knowledge and facilities for processing harvested latex are still out of reach for most farmers. An embrace of rubber as the main crop, as observed elsewhere in Southeast Asia [55,58], has not become apparent in our case study.

Most of the money spent by players was allocated to improving their standard of living before allocating it to any income-generating activity. This likely reflects the high importance the workshop participants attributed to their quality of life. During the game, players would compare how much others had invested into standard of living parameters such as education, housing, or family, and would spend considerable time deciding in which category to invest. Amongst the different standard of living categories available in the game, players invested the most into education. Though free, the local schools were considered by the participants to be of very low quality, with children going to school just to receive the free state-funded lunch, instead of education. To the parents, it is paramount that their children need to be well-educated to have a chance of escaping poverty. Only those that are unable to are likely to be the next generation of jhum farmers. One concern issued by the game workshop participants is that sending children off to boarding schools bears the complication that children and teenagers would no longer be doing farm chores, resulting in a loss of skills and the motivation to continue the hard-labour jhum farming. The difficulty to enter and succeed in the school system, and the job market afterwards, as voiced by the Karbi participants, is reflective of India's primary and higher education system, which still suffers from high inequalities based on caste and ethnicity [59].

The choices and decisions of the farmers in the game impacted the landscape which transitioned from a forest and wild bamboo dominated landscape towards a planted bamboo dominated landscape with few rubber and tea plantations. Most harvestable planted bamboo was left standing, with labour remaining a major constraint to maximising income. The farmers also reported to keep the bamboo for financial emergencies. The traditional jhum system has only recently seen the introduction of bamboo gardens as an improved fallow [45,60,61]. As time progressed in the game, these fallows took over, while the first plantations slowly appeared in the game landscape. The planted bamboo was 
described by some of the players to be a stepping-stone that allows for investments in tea and rubber at a later stage. Once local processing infrastructure gets developed and highway access to international markets, especially China and Myanmar, two important rubber producers [55], is improved, some farmers might be keen to transition.

\section{Conclusions}

Though jhum is perceived as hard and intense work and carries a high risk of loss to wildlife, farmers prioritised jhum cultivation over the more economically lucrative tea and rubber plantations. Abandoning shifting agriculture for other land uses and practices obviously is not just an economic affair; where livelihoods are at risk, or, where vulnerabilities to change and risks of failure are difficult to grasp, as people favour the current system. Farmers are, however, willing to explore new opportunities, and most of the players established at least one small plantation. When asked how the farmers viewed the changes in the landscape that occurred during the game sessions, the response was that the changes were good, providing them with more income. Throughout the simulations, it was evident that the farmers were actively trying to secure a better livelihood for their children. Both investing in education, and establishing plantations were seen as a means for the next generation to escape poverty. However, in the game, as well as during the debriefing, farmers showed reluctance to give up their Jhum for a new system. This is related to the safety component of diversified systems, which carry less uncertainties and risks than more intensive land use systems [4].

This study gives us an understanding of the priorities and strategies of the jhum farmers when new opportunities arrive. The observed trends in the game landscape represent possible futures of the system, within the limitations of the current socio-economic and biophysical conditions in place. Whether these changes are desirable or not is not up to us to decide. Instead, we hope these results help create a better understanding of the system dynamics and jhum farmer strategies. This study can serve as a starting point of a respectful dialogue between the different stakeholders, hopefully leading to an environment where both the farmers, with their needs and aspirations, and the government, with its mandate to preserve Kaziranga's wildlife habitats, can sustainably and peacefully coexist.

Supplementary Materials: The following are available online at http://www.mdpi.com/2071-1050/12/6/2438/s1, Table S1: Market prices of different items that can be sold to the farmers, or bought from the farmers, Table S2: The yields of the different Jhum crop type, for different Jhum field soil fertility conditions per planted seed package, Table S3: Plantation crop investments and returns, Video S1: Jhum model mechanics.

Author Contributions: Conceptualization, S.P.M.B. and C.A.G.; Methodology, S.P.M.B., A.D., P.O.W. and C.A.G.; Validation, A.D., P.O.W. and C.A.G.; Formal Analysis, S.P.M.B. and T.C.; Investigation, S.P.M.B.; Resources, S.P.M.B.; Data Curation, S.P.M.B. and T.C.; Writing-Original Draft Preparation, S.P.M.B., T.C.; Writing-Review \& Editing, A.D., P.O.W. and C.A.G.; Visualization, S.P.M.B. and T.C.; Supervision, C.A.G.; Project Administration, S.P.M.B.; Funding Acquisition, S.P.M.B., P.O.W. and C.A.G. All authors have read and agreed to the published version of the manuscript.

Funding: This study was funded by ETH Grants, ETH Research (Grant ETH-53 13-2) from ETH Zurich, Switzerland, as part of the PhD project of the first author.

Acknowledgments: We would like to give our sincere thanks to the research assistants that supported us during the intense fieldwork. Charlish Singnar, Lydia Ronghangpi, Nelson Deb, Moniram Teron, Franklin Rongphar and Serlibon Timungpi were instrumental in making this study a success. We would also like to thank the French Institute of Pondicherry and the Karbi Anglong Autonomous District Council for their administrative support in India. Last but not least we would like to thank all the participating farmers for their generous sharing of their knowledge and time. This study was funded by ETH Grants, ETH Research (Grant ETH-53 13-2) from ETH Zurich, Switzerland, as part of the PhD project of the first author. The study was given retro-active approval without reservations by the ETH Zurich Ethics Commission (EK 2019-N-73).

Conflicts of Interest: The authors declare no conflict of interest. 


\section{References}

1. Heinimann, A.; Mertz, O.; Frolking, S.; Christensen, A.E.; Hurni, K.; Sedano, F.; Chini, L.P.; Sahajpal, R.; Hansen, M.; Hurtt, G. A global view of shifting cultivation: Recent, current, and future extent. PLoS ONE 2017, 12, e0184479. [CrossRef] [PubMed]

2. Brady, N.C. Alternatives to slash-and-burn: A global imperative. Agric. Ecosyst. Environ. 1996, 58, 3-11. [CrossRef]

3. Mertz, O.; Leisz, S.J.; Heinimann, A.; Rerkasem, K.; Dressler, W.; Pham, V.C.; Vu, K.C.; Schmidt-Vogt, D.; Colfer, C.J.; Epprecht, M.; et al. Who counts? Demography of swidden cultivators in Southeast Asia. Hum. Ecol. 2009, 37, 281-289. [CrossRef]

4. van Vliet, N.; Mertz, O.; Heinimann, A.; Langanke, T.; Pascual, U.; Schmook, B.; Adams, C.; Schmidt-Vogt, D.; Messerli, P.; Leisz, S.; et al. Trends, drivers and impacts of changes in swidden cultivation in tropical forest-agriculture frontiers: A global assessment. Glob. Environ. Chang. 2012, 22, 418-429. [CrossRef]

5. Fox, J.; Vogler, J.B. Land-use and land-cover change in montane mainland Southeast Asia. Environ. Manag. 2005, 36, 394-403. [CrossRef] [PubMed]

6. Robiglio, V.; Sinclair, F. Maintaining the conservation value of shifting cultivation landscapes requires spatially explicit interventions. Environ. Manag. 2011, 48, 289-306. [CrossRef]

7. Adams, C.; Munari, L.C.; Van Vliet, N.; Murrieta, R.S.; Piperata, B.A.; Futemma, C.; Pedroso, N.N.; Taqueda, C.S.; Crevelaro, M.A.; Spressola-Prado, V.L. Diversifying incomes and losing landscape complexity in Quilombola shifting cultivation communities of the Atlantic Rainforest (Brazil). Hum. Ecol. 2013, 41, 119-137. [CrossRef]

8. Hurni, K.; Hett, C.; Heinimann, A.; Messerli, P.; Wiesmann, U. Dynamics of shifting cultivation landscapes in northern Lao PDR between 2000 and 2009 based on an analysis of MODIS time series and Landsat images. Hum. Ecol. 2013, 41, 21-36. [CrossRef]

9. Cairns, M.F. Shifting Cultivation and Environmental Change: Indigenous People, Agriculture and Forest Conservation; Routledge: Abingdon, UK, 2015.

10. Cochard, R.; Ngo, D.T.; Waeber, P.O.; Kull, C.A. Extent and causes of forest cover changes in Vietnam's provinces 1993-2013: A review and analysis of official data. Environ. Rev. 2017, 25, 199-217. [CrossRef]

11. Fox, J.; Fujita, Y.; Ngidang, D.; Peluso, N.; Potter, L.; Sakuntaladewi, N.; Sturgeon, J.; Thomas, D. Policies, political-economy, and swidden in Southeast Asia. Hum. Ecol. 2009, 37, 305-322. [CrossRef]

12. Mertz, O.; Padoch, C.; Fox, J.; Cramb, R.A.; Leisz, S.J.; Lam, N.T.; Vien, T.D. Swidden change in Southeast Asia: Understanding causes and consequences. Hum. Ecol. 2009, 37, 259-264. [CrossRef]

13. Bruun, T.B.; De Neergaard, A.; Lawrence, D.; Ziegler, A.D. Environmental consequences of the demise in swidden cultivation in Southeast Asia: Carbon storage and soil quality. Hum. Ecol. 2009, 37, 375-388. [CrossRef]

14. Rerkasem, K.; Lawrence, D.; Padoch, C.; Schmidt-Vogt, D.; Ziegler, A.D.; Bruun, T.B. Consequences of swidden transitions for crop and fallow biodiversity in Southeast Asia. Hum. Ecol. 2009, 37, 347-360. [CrossRef]

15. Cramb, R.A.; Colfer, C.J.; Dressler, W.; Laungaramsri, P.; Le, Q.T.; Mulyoutami, E.; Peluso, N.L.; Wadley, R.L. Swidden transformations and rural livelihoods in Southeast Asia. Hum. Ecol. 2009, 37, 323-346. [CrossRef]

16. Feintrenie, L.; Schwarze, S.; Levang, P. Are local people conservationists? Analysis of transition dynamics from agroforests to monoculture plantations in Indonesia. Ecol. Soc. 2010, 15, 37. [CrossRef]

17. Dressler, W.H.; Wilson, D.; Clendenning, J.; Cramb, R.; Keenan, R.; Mahanty, S.; Bruun, T.B.; Mertz, O.; Lasco, R.D. The impact of swidden decline on livelihoods and ecosystem services in Southeast Asia: A review of the evidence from 1990 to 2015. Ambio 2017, 46, 291-310. [CrossRef]

18. Neog, A.K. Transforming hill agriculture in tribal areas in north-east India. In Trends in Agrarian Structure in the Hills of North-East India; Behera, M.C., Roy, N.C., Eds.; Commonwealth Publishers: New Delhi, India, 1997; pp. 99-108.

19. Teron, R.; Borthakur, S.K. Traditional knowledge relating to use of flora and fauna as indicators in predicting annual seasons among Karbi tribe of Assam. Indian J Tradit. Knowl. 2009, 8, 518-524.

20. Darlong, V. Reflections on the impacts of state policies on shifting cultivators in northeast India. In Shifting Cultivation Policies: Balancing Environmental and Social Sustainability; CABI International: Boston, MA, USA, 2017; pp. 344-378. 
21. Krishna, S. Agriculture and a Changing Environment in Northeastern India; Routledge: New Delhi, India, 2012.

22. Speelman, E.; Jager, W.; Groot, J.C.; Garcia-Barrios, P.; Tittonell, P. Multilevel simulation of farmer's land use and social organization decision-making; an agent-based approach. In Modeling Social Phenomena in Spatial Context; LIT Verlag GmbH \& Co. KG: Wien, Austria, 2013; Volume 2, pp. 63-69.

23. Basco-Carrera, L.; Warren, A.; van Beek, E.; Jonoski, A.; Giardino, A. Collaborative modelling or participatory modelling? A framework for water resources management. Environ. Model. Softw. 2017, 91, 95-110. [CrossRef]

24. Redpath, S.M.; Keane, A.; Andrén, H.; Baynham-Herd, Z.; Bunnefeld, N.; Duthie, A.B.; Frank, J.; Garcia, C.A.; Månsson, J.; Nilsson, L.; et al. Games as tools to address conservation conflicts. Trends Ecol. Evol. 2018, 33, 415-426. [CrossRef]

25. Singh, M.A. Ethnic diversity, autonomy, and territoriality in Northeast India: A case of tribal autonomy in Assam. Strateg. Anal. 2008, 32, 1101-1114. [CrossRef]

26. Heinen, J.T.; Shrivastava, R.J. An analysis of conservation attitudes and awareness around Kaziranga National Park, Assam, India: Implications for conservation and development. Popul. Environ. 2009, 30, 261-274. [CrossRef]

27. Barbora, S. Autonomous districts and/or ethnic homelands: An ethnographic account of the genesis of political violence in Assam (North-East India) against the normative frame of the Indian constitution. Int. J. Minority Group Rights 2008, 15, 313-334. [CrossRef]

28. Grogan, P.; Lalnunmawia, F.; Tripathi, S.K. Shifting cultivation in steeply sloped regions: A review of management options and research priorities for Mizoram state, Northeast India. Agrofor. Syst. 2012, 84, 163-177. [CrossRef]

29. Schmid, T. A Remote Sensing Perspective on the Impact of Shifting Cultivation (Jhum) on the Forest Structure in Northern Karbi Anglong, Assam, India. Master's Thesis, Environmental Sciences, ETH Zurich, Zurich, Switzerland, 2016.

30. Campo, P.C.; Bousquet, F.; Villanueva, T.R. Environmental modelling and software modelling with stakeholders within a development project. Environ. Model. Softw. 2010, 25, 1302-1321. [CrossRef]

31. Etienne, M.; Du Toit, D.R.; Pollard, S. ARDI: A co-construction method for participatory modeling in natural resources management. Ecol. Soc. 2011, 16. Available online: http://www.ecologyandsociety:vol16/iss1/art44/ (accessed on 20 December 2019). [CrossRef]

32. Étienne, M. Companion Modelling, a Participatory Approach to Support Sustainable Development; Quae: Versailles, France; Springer: Dordrecht, The Netherlands, 2014.

33. Bousquet, F.; Barreteau, O.; Le Page, C.; Mullon, C.; Weber, J. An environmental modelling approach: The use of multi-agent simulations. In Advances in Environmental and Ecological Modelling; Elsevier: Paris, France, 1999; pp. 113-122.

34. Bousquet, F.; Trébuil, G.; Hardy, B. Companion Modeling and Multi-Agent Systems for Integrated Natural Resource Management in Asia; International Rice Research Institute: Los Baños, Philippines, 2005.

35. Dumrongrojwatthana, P.; Trébuil, G. Northern Thailand case: Gaming and simulation for co-learning and collective action. In Companion Modelling for Collaborative Landscape Management between Herders and Foresters; Wageningen Academic Publishers: Wageningen, The Netherlands, 2011; pp. 191-219.

36. Reibelt, L.M.; Moser, G.; Dray, A.; Randriamalala, I.H.; Chamagne, J.; Ramamonjisoa, B.; Barrios, L.G.; Garcia, C.; Waeber, P.O. Tool development to understand rural resource users' land use and impacts on land type changes in Madagascar. Madag. Conserv. Dev. 2019. [CrossRef]

37. Garcia, C.; Vendé, J.; Konerira, N.; Kalla, J.; Nay, M.M.; Dray, A.; Delay, M.; Waeber, P.; Stoudmann, N.; Bose, A.; et al. Understanding coffee farmers: Using games to explore future coffee agroforestry landscapes in the Western Ghats (India). AgriXiv 2018. [CrossRef]

38. Castella, J.C.; Trung, T.N.; Boissau, S. Participatory simulation of land-use changes in the northern mountains of Vietnam: The combined use of an agent-based model, a role-playing game, and a geographic information system. Ecol. Soc. 2005, 10. [CrossRef]

39. Toky, O.P.; Ramakrishnan, P.S. Secondary succession following slash and burn agriculture in North-Eastern India: Biomass, litterfall and productivity. J. Ecol. 1983, 71, 735-745. [CrossRef]

40. Garcia, C.; Dray, A.; Waeber, P. Learning begins when the game is over: Using games to embrace complexity in natural resources management. GAIA Ecol. Perspect. Sci. Soc. 2016, 25, 289-291. [CrossRef] 
41. Stoeckli, B.; Wiesmann, U.; Lys, J.A. A Guide for Transboundary Research Partnerships: 11 Principles and 7 Questions, 2nd ed.; Swiss Commission for Research Partnerships with Developing Countries (KFPE): Bern, Switzerland, 2014.

42. R Development Core Team. R: A Language and Environment for Statistical Computing; R Foundation for Statistical Computing: Vienna, Austria, 2008.

43. Wood, S.N. Fast stable restricted maximum likelihood and marginal likelihood estimation of semiparametric generalized linear models. J. R. Stat. Soc. 2011, 73, 3-36. [CrossRef]

44. Bates, D.; Mächler, M.; Bolker, B.M.; Walker, S.C. Fitting linear mixed-effects models using lme4. J. Stat. Softw. 2015, 67, 1-48. [CrossRef]

45. Shrivastava, R.J.; Heinen, J.T. Migration and home gardens in the Brahmaputra Valley, Assam, India. J. Ecol. Anthropol. 2005, 9, 20-34. [CrossRef]

46. Shrivastava, R.J.; Heinen, J. A microsite analysis of resource use around Kaziranga National Park, India: Implications for conservation and development planning. J. Environ. Dev. 2007, 16, 207-226. [CrossRef]

47. Wangpan, T.; Tangjang, S. Significance of mixed-cropping in jhum based traditional agroforestry in Tirap and Longding District of Arunachal Pradesh, India. J. Bioresour. 2015, 2, 62-73.

48. Behera, R.N.; Nayak, D.K.; Andersen, P.; Måren, I.E. From jhum to broom: Agricultural land-use change and food security implications on the Meghalaya Plateau, India. Ambio 2016, 45, 63-77. [CrossRef]

49. Trenbath, B.R. Multispecies cropping systems in India: Predictions of their productivity, stability, resilience and ecological sustainability. Agrofor. Syst. 1999, 45, 81-107. [CrossRef]

50. Hansen, T.S.; Mertz, O. Extinction or adaptation? Three decades of change in shifting cultivation in Sarawak, Malaysia. Land Degrad. Dev. 2006, 17, 135-148. [CrossRef]

51. Bodonirina, N.; Reibelt, L.M.; Stoudmann, N.; Chamagne, J.; Jones, T.G.; Ravaka, A.; Ranjaharivelo, H.V.; Ravonimanantsoa, T.; Moser, G.; De Grave, A.; et al. Approaching local perceptions of forest governance and livelihood challenges with companion modeling from a case study around Zahamena National Park, Madagascar. Forests 2018, 9, 624. [CrossRef]

52. Das, N.K. Making of tea tribes in Assam: Colonial exploitation and assertion of Adivasi rights. J. Adivasi Indig. Stud. 2016, IV, 1-16.

53. Mackenzie, C.A.; Ahabyona, P. Elephants in the garden: Financial and social costs of crop raiding. Ecol. Econ. 2012, 75, 72-82. [CrossRef]

54. Awasthi, R.C. Economics of Tea Industry in India; United Publishers: Gauhati, India, 1975.

55. Fox, J.; Castella, J.-C. Expansion of rubber (Hevea brasiliensis) in mainland Southeast Asia: What are the prospects for smallholders? J. Peasant Stud. 2013, 40, 155-170. [CrossRef]

56. Levang, P.; Michon, G.; De Foresta, H.; Verdeaux, F. Domestic forests: A new paradigm for integrating local communities' forestry into tropical forest science. Ecol. Soc. 2007, 12. [CrossRef]

57. Talukdar, N.R.; Choudhury, P. Conserving wildlife wealth of Patharia Hills Reserve Forest, Assam, India: A critical analysis. Glob. Ecol. Conserv. 2017, 10, 126-138. [CrossRef]

58. Ziegler, A.D.; Fox, J.M.; Xu, J. The rubber juggernaut. Science 2009, 324, 1024-1025. [CrossRef]

59. Desai, S.; Kulkarni, V. Changing educational inequalities in India in the context of affirmative action. Demography 2008, 45, 245-270. [CrossRef]

60. Das, T.; Das, A.K. Inventorying plant biodiversity in homegardens: A case study in Barak Valley, Assam, North East India. Curr. Sci. 2005, 89, 155-163.

61. Nath, A.J.; Das, A.K. Bamboo resources in the homegardens of Assam: A case study from Barak Valley. J. Trop. Agric. 2008, 46, 46-49.

(C) 2020 by the authors. Licensee MDPI, Basel, Switzerland. This article is an open access article distributed under the terms and conditions of the Creative Commons Attribution (CC BY) license (http://creativecommons.org/licenses/by/4.0/). 